\title{
ХАРАКТЕРИСТИКА СТРЕС-ФАКТОРІВ, ЩО ВПЛИВАЮТЬ НА ПЕРЕДСТАРТОВИЙ СТАН ЛЕГКОАТЛЕТІВ-СПРИНТЕРІВ
}

\author{
Тетяна Суворова ${ }^{1}$, Володимир Ковальчук ${ }^{1}$, Наталія Денисенко ${ }^{1}$, Михайло Мороз ${ }^{1}$, \\ Олександр Радченко \\ ${ }^{1}$ Луцький педагогічний коледж, Луцьк, Україна, Suvtatjana@gmail.com \\ 2Луцький національний технічний університет, Луцьк, Україна
}

https://doi.org/10.29038/2220-7481-2020-03-74-81

\begin{abstract}
Анотації
Актуальність дослідження. У статті узагальнено сучасні наукові дані щодо важливості психологічної підготовки легкоатлетів-спринтерів до змагальної діяльності, представлено результати психолого-педагогічного експерименту, визначено основні чинники, що впливають на психологічний стан у різні періоди підготовки спортсменів. Мета дослідження - виявити найбільш значні стрес-фактори, які впливають на психологічний стан легкоатлетів-спринтерів під час підготовки й участі в змаганнях. Завдання дослідження - визначити ступінь розробленості досліджуваної проблеми в теорії та практиці спортивного тренування; виявити найбільш значні стрес-фактори, що впливають на психіку спортсменів у процесі змагальної діяльності. Методи дослідження - теоретичний аналіз й узагальнення літературних джерел, педагогічні спостереження, опитування (бесіда, анкетування), методи математичної статистики. Учасники дослідження. У дослідженні брали участь учні ДЮСШ м. Луцька, студенти фізичної культури, спорту та здоров'я СНУ ім. Лесі Українки та студенти Луцького технічного університету (20 осіб), які займалися спринтом і мали різні спортивні розряди. Результати дослідження. Для виявлення значущих стрес-факторів, що впливають на психологічний стан спортсменів, у процесі змагальної діяльності використано опитувальник Р. Фрестера «Стрес-симптом-тест». За його результатами з'ясовано, що для висококваліфікованих легкоатлетів-спринтерів найбільш значними стресфакторами $є$ проведення напередодні неякісних тренувань; поганий сон перед змаганням; підвищене хвилювання й надмірна напруженість на старті; зустріч із сильнішим суперником; невдалий виступ на попередніх змаганнях; негативні реакції глядачів. Аналізуючи стан і поведінку низькокваліфікованих спортсменів у відповідь на дію різних стрес-факторів, встановили, що деякі $з$ них $є$ також однаково важливими для спортсменів. Висновки. Визначення основних чинників, які перешкоджають успішній діяльності спортсменів, дасть змогу тренерам передбачати можливі негативні наслідки, які впливають на готовність спортсменів до змагальної діяльності, та проводити відповідну коригувальну роботу.
\end{abstract}

Ключові слова: змагання, легкоатлети-спринтери, передстартовий стан, психологічна підготовка, фізична підготовка.

Татьяна Суворова, Владимир Ковальчук, Наталья Денисенко, Михаил Мороз, Александр Радченко. Характеристика стресс-факторов, влияющих на предстартовое состояние легкоатлетов-спринтеров. Актуальность исследования. В данной статье обобщаются современные научные данные о важности психологической подготовки легкоатлетов-спринтеров, к соревновательной деятельности, представляются результаты психолого-педагогического эксперимента, определяются основные факторы, влияющие на психологическое состояние в разные периоды подготовки спортсменов. Цель исследования - выявить наиболее значимые стресс-факторы, которые влияют на психологическое состояние легкоатлетов-спринтеров при подготовке и участии в соревнованиях. Задачи исследования - определить степень разработанности исследуемой проблемы в теории и практике спортивной тренировки; выявить наиболее значимые стресс-факторы, влияющие на психику спортсменов в процессе соревновательной деятельности. Методы исследования теоретический анализ и обобщение литературных источников, педагогические наблюдения, опроса (беседа, анкетирование), методы математической статистики. Участники исследования. В исследовании принимали участие учащиеся ДЮСШ г. Луцка, студенты физической культуры, спорта и здоровья СНУ им. Леси Украинки и студенты Луцкого технического университета (20 человек), которые занимались спринтом и имели различные спортивные разряды. Результаты исследования. Для выявления наиболее значимых стресс-факторов, влияющих на психологическое состояние спортсменов в процессе соревновательной деятельности использовался опросник Р. Фрестера «Стресс симптом-тест». По результатам опроса выяснено, что для высококвалифицированных легкоатлетов-спринтеров наиболее значимыми стресс-факторами являются проведение накануне некачественных тренировок; плохой сон перед соревнованием; повышенное волнение и чрезмерная напряженность на старте; встреча с сильным соперником; неудачное выступление на предыдущих соревнованиях; негативные реакции зрителей. Анализируя состояние и поведение низкоквалифицированных спорт- 
сменов в ответ на действие различных стресс-факторов, установили, что некоторые из них также одинаково значимые для спортсменов. Выводы. Определение основных факторов, препятствующих успешной деятельности спортсменов, позволит тренерам предвидеть возможные негативные последствия, которые влияют на готовность спортсменов к соревновательной деятельности, и проводить соответствующую корректирующую работу.

Ключевые слова: соревнования, легкоатлеты-спринтеры, предстартовое состояние, психологическая подготовка, физическая подготовка.

Tetiana Suvorova, Volodymyr Kovalchuk, Nataliia Denysenko, Mykhailo Moroz, Oleksandr Radchenko. Stress Factors Characteristics Affecting the Pre-Start State of Sprint Athletes. Research Relevance. The article generalizes contemporary scientific data concerning the significance of psychological preparedness of sprint athletes to the competitive activities; the results of psychological and pedagogical experiment are presented, the main factors that influence the psychological state in different preparation periods of athletes are defined. The Research Aimed to identify the most significant stress factors that affect the psychological state of sprint athletes during training and participation in competitions. Research Objectives were to determine the level of development of the studied issue in the theory and practice of sports training; to identify the most significant stress factors that affect the psyche of athletes in the process of competitive activity. Research Methods include theoretical analysis and generalization of literary sources, pedagogical observations, surveys (interviews, questionnaires), and mathematical statistics methods. Research Subjects. Students of Lutsk Children and Youth Sports School (CYSS), students of physical education, sports and health of Lesya Ukrainka Eastern European National University, and students of Lutsk Technical University (20 people) engaged in sprinting and had different sports categories participated in the study. Research Results. R. Frester's questionnaire «Stress-symptom-test» was used to identify the most significant stress factors that affect the psychological state of athletes in the process of a competitive activity. The survey results determined that the most significant stress factors for the high qualified sprint athletes were conduction of low-quality training before; bad sleep before the competition; increased excitement and excessive tension at the start; meeting with a stronger opponent; unsuccessful performance at previous competitions; negative reactions of spectators. Analyzing the state and behaviour of low-qualified athletes in response to different stress factors, it was determined that some of them are equally significant for sportsmen. Conclusions. Identifying the main factors that interfere successful performance of athletes allow coaches to anticipate possible negative consequences that affect the readiness of sportsmen for a competitive activity and conduct the appropriate corrective work.

Key words: competitions, sprint athletes, pre-start state, psychological training, physical training.

Вступ. Спортивні змагання - найважливіша й невід’ємна частина спортивної діяльності. Вони вимагають від спортсменів максимальної фізичної та психічної напруги й характеризуються високою емоційністю. У ході змагань одні емоції змінюють інші: позитивні - радість, успіхи, тріумфування, упевненість; негативні - засмучення у зв'язку з помилкою. допущеною на старті, досада, незадоволеність, відчай, гіркота поразки.

Кожен спортсмен підходить до старту в певному психологічному стані. I часто такий психологічний стан стає причиною виникнення низки передстартових психічних дисгармоній або станів, які негативно впливають на результат.

Протягом багатьох років різними науковцями зроблено спроби дослідити особливості передстартових робочих психічних станів спортсменів, а також виявити чинники, що впливають на них.

В. Н. Волков, А. А. Лалаян, А. В. Радіонов [1; 6; 12] серед основних чинників, що впливають на спортивний результат, виділяють стан здоров'я, особові властивості й умови змагань.

А. Д. Ганюшкін [3] указує, що такими чинниками є вік, стаж спортсмена, морфологічні ознаки, функціональні можливості, рівень усіх сторін підготовленості.

В. Н. Платонов [11] відзначає такі чинники, як загальний режим й умови життя, лікарськомедичне та науково-методичне забезпечення тренувального процесу.

Деякі дослідники вивчали вплив на передстартовий стан соціально-демографічних чинників, таких як стать, вік, рівень кваліфікації, спортивний стаж, вид спорту та ін. $[4 ; 5 ; 7 ; 8]$.

Щоб досягти вершин спортивної майстерності, спортсмену потрібно багато працювати над удосконаленням усіх сторін спортивної підготовки, а саме: фізичної, тактичної, технічної й психічної. Недопрацювання однієї складової частини може негативно вплинути на тривалий процес підготовки, та спортсмен не зможе досягти по-справжньому високих результатів.

Багато тренерів у своїй роботі найчастіше віддають перевагу розвитку фізичної, технічної й тактичної підготовки. Психологічна підготовка для них займає другорядне місце. Але це хибна 
думка. Психологічна підготовка $є$ необхідним компонентом процесу формування готовності до змагання спортсменів будь-якої кваліфікації.

Практика спортивної діяльності доводить, що один із головних компонентів у спорті - це рівень фізичної підготовленості. Але, якщо спортсмен не вміє володіти своїм психічним станом, таким, наприклад, як зустріч із сильнішим супротивником, високий масштаб спортивного змагання, вимоги керівництва й тренера щодо виконання нормативу для потрапляння в збірну команду або продовження контракту, переживання від минулих невдалих виступів, він може не впоратися 3 психічним навантаженням і показати результат нижчий від своїх можливостей.

Особливо це питання актуальне в спринтерських дисциплінах легкої атлетики, де результат залежить від однієї сотої, а то й тисячної долі секунди. Тому сьогодні, коли технічна й фізична підготовленість провідних спортсменів досить висока та приблизно однакова, перемогу здобуває той спортсмен, який може чітко й усвідомлено керувати своїм психічним станом на етапі безпосередньої підготовки та під час виступу на змаганні. Рівень підготовки спортсмена багато в чому визначається тим, як він зуміє провести останні дні й години перед відповідальними змаганнями [4].

Важливим для спортсмена та тренера на етапі підготовки до змагань $є$ знання чинників, які безпосередньо впливають на спортивний результат, уміння контролювати прояви й причини виникнення психічного стану, відволікатися від дії негативних стрес-факторів, використовувати спеціальні прийоми для мобілізації на досягнення найкращих результатів $[2,13]$.

Мета дослідження - виявити найбільш значні стрес-фактори, які впливають на психологічний стан легкоатлетів-спринтерів у процесі змагальної діяльності.

Матеріал і методи дослідження. Для досягнення поставленої мети проведено теоретичний аналіз та узагальнення літературних джерел із питань психологічної підготовки спортсменів, психологічні спостереження й анкетування спортсменів та їхніх тренерів, методи математичної статистики.

Педагогічні спостереження реалізовано задля виявлення особливостей змагальної й тренувальної діяльності спортсменів, особливостей їхньої поведінки в період підготовки та участі в змаганнях. За результатами спостережень проводили групові й індивідуальні бесіди та опитування спортсменів (табл. 1).

Для оцінки поведінки спортсменів на змаганнях і значущості саморегуляції в спорті опитано тренерів легкоатлетів (табл. 2).

Дані анкетного опитування обробляли методами математичної статистики, що забезпечують кількісний і якісний аналіз. За допомогою програмного забезпечення («Microsoft-Excel» для Windows

ХР) визначали середнє арифметичне $(\bar{X})$ і середнє квадратичне відхилення $(\sigma)$.

У досліджені взяли участь 20 легкоатлетів-спринтерів другого й першого спортивних розрядів, кандидати та майстри спорту віком 18-24 роки, учні ДЮСШ м. Луцька, студенти СНУ ім. Лесі Українки й Луцького НТУ, які успішно виступали на обласних і всеукраїнських змаганнях. Дослідження проводили впродовж змагального періоду 2019 р.

Результати дослідження. Проаналізувавши науково-методичну літературу, яка стосується цієї проблеми, результати опитування й дані психологічних спостережень, ми з'ясували, що способам психічної саморегуляції спортсмен повинен навчатися в процесі всієї тренувальної й змагальної діяльності, де важливе місце займає правильність оцінки свого психічного стану. Це питання в наших дослідженнях вирішувалося за допомогою опитувальника «Стрес-сімптом-тест» Р. Фрестера. Він дав змогу визначити найбільш значні стрес-фактори, що негативно впливають на психіку спортсмена напередодні та під час змагання (табл. 1).

Таблиия 1

Значущість стрес-факторів у спортивній діяльності легкоатлетів-спринтерів (кількість випадків, \%)

\begin{tabular}{|c|c|c|c|}
\hline $\begin{array}{c}\text { № } \\
\text { 3/II }\end{array}$ & Стрес-фактор & $\begin{array}{c}\text { Легкоатлети } \\
\text { високої } \\
\text { кваліфікації } \\
(\mathbf{n = 1 0 )}\end{array}$ & $\begin{array}{c}\text { Легкоатлети } \\
\text { низької } \\
\text { кваліфікації } \\
\text { (n=10) }\end{array}$ \\
\hline $\mathbf{1}$ & $\mathbf{2}$ & $\mathbf{3}$ & $\mathbf{4}$ \\
\hline 1 & Невдача на старті & 30 & 40 \\
\hline
\end{tabular}


Закінчення таблищі 1

\begin{tabular}{|c|c|c|c|}
\hline 1 & 2 & 3 & 4 \\
\hline 2 & Попередні погані тренування й низькі результати змагань & 78 & 66 \\
\hline 3 & Конфлікти $з$ тренером, товаришами по команді або в сім’ї & 30 & 70 \\
\hline 4 & Погане самопочуття відносно фізичного стану & 40 & 20 \\
\hline 5 & Необ’єктивне суддівство & 30 & 10 \\
\hline 6 & Відтермінування старту, початку змагання & 20 & 10 \\
\hline 7 & Положення фаворита перед змаганням & 0 & 20 \\
\hline 8 & Докори тренера, товаришів під час виступу & 40 & 40 \\
\hline 9 & Надмірна напруженість на старті & 50 & 65 \\
\hline 10 & $\begin{array}{l}\text { Підвищене хвилювання, поганий сон за один або декілька } \\
\text { днів до змагання }\end{array}$ & 72 & 40 \\
\hline 11 & Погане матеріальне оснащення & 20 & 30 \\
\hline 12 & Попередня невдача на змаганні & 42 & 20 \\
\hline 13 & Значна перевага суперників & 10 & 10 \\
\hline 14 & Несподівано високі результати суперників & 55 & 30 \\
\hline 15 & Незнайомий суперник & 10 & 10 \\
\hline 16 & Завищені вимоги тренера & 20 & 10 \\
\hline 17 & Тривалий переїзд до місця змагання & 30 & 20 \\
\hline 18 & $\begin{array}{l}\text { Постійно нав’язлива думка про } \\
\text { необхідність успішно виконати завдання }\end{array}$ & 20 & 40 \\
\hline 19 & Зорові, акустичні й тактильні перешкоди & 30 & 10 \\
\hline 20 & Попередня поразка від майбутнього супротивника & 10 & 0 \\
\hline 21 & Негативні реакції глядачів & 25 & 35 \\
\hline
\end{tabular}

Результати опитування засвідчили, що для висококваліфікованих легкоатлетів-спринтерів найбільш значними стрес-факторами $є$ попередні погані тренування й низькі результати змагань (78 \%); підвищене хвилювання, поганий сон за один або декілька днів до змагання (72 \%); надмірну напруженість на старті (50 \%); несподівано високі результати суперників (55 \%); погане самопочуття відносно фізичного стану (40\%); докори тренера, товаришів під час виступу (40\%); попередню невдачу на змаганні (42\%); негативні реакції глядачів (25\%).

Легкоатлети нижчого рівня підготовленості до значущих стрес-факторів віднесли попередні погані тренування й низькі результати змагань ( $66 \%$ ); конфлікти з тренером, товаришами по команді або в сім'ї (70 \%); надмірну напруженість на старті (65\%); підвищене хвилювання, поганий сон за один або декілька днів до змагання (40 \%); невдачу на старті (40\%), докори тренера, товаришів під час виступу (40 \%); постійна думка про необхідність успішно виконати поставлені завдання (40\%).

Аналізуючи стан і поведінку спортсменів у відповідь на дію різних стрес-факторів в обох групах, ми прийшли до висновку, що деякі з них є однаково значущими для спортсменів. Зокрема, такими $\epsilon$ попередні погані тренування й низькі результати змагань; докори тренера, товаришів під час виступу; надмірна напруженість на старті; підвищене хвилювання, поганий сон до змагання, негативний вплив глядачів.

Визначено стрес-фактори, що негативно впливають на психіку спортсмена напередодні та під час змагання, указують на необхідність навчати спортсменів контролювати свій передстартовий стан і поведінку.

Аналіз опитування тренерів про особливості поведінки й психічний стан легкоатлетівспринтерів на змаганнях (табл. 2) засвідчив, що перед стартом 35 \% висококваліфікованих легко- 
атлетів-спринтерів перебувають у стані повної бойової готовності, 30 \% - у стані підвищеного та $30 \%$ - сильного збудження, а 5 \% - відчувають повний спокій.

Спортсмени нижчої кваліфікації, перед стартом, у більшості випадків перебувають у стані сильного психологічного збудження - 34,5; 31,5 \% - у стані бойовій готовності, 20,5 \% - відчувають незначне підвищене збудження, 13,5 \% - повний спокій.

Зазначимо, що передстартові стани по-різному впливають на змагальну діяльність спортсмена й на досягнення ним спортивного результату $[1,3]$. Стан бойової готовності є найбільш сприятливим щодо цього. Стан надмірного загального збудження, типовий для стану стартової лихоманки, дезорганізовує діяльність - і спортсмен утрачає можливість правильно контролювати розподіл своїх сил на дистанції. Повний спокій або стартова апатія нерідко впливають і не дають змоги спортсмену досягти успіху на змаганні $[5,15]$.

Таблицяя 2

\section{Поведінка й психічний стан легкоатлетів-спринтерів на змаганнях (кількість випадків, \%)}

\begin{tabular}{|c|c|c|c|}
\hline \multicolumn{2}{|c|}{ Особливості поведінки та психічного стану } & $\begin{array}{c}\text { Спортсмени } \\
\text { високої квалі- }\end{array}$ & $\begin{array}{l}\text { Спортсмени } \\
\text { низької ква- }\end{array}$ \\
\hline \multirow{5}{*}{$\begin{array}{l}\text { 1. Психічний } \\
\text { стан спортсменів } \\
\text { перед стартом }\end{array}$} & а) сильне збудження & 30 & 34,5 \\
\hline & б) оптимальний бойовий стан & 35 & 31,5 \\
\hline & в) підвищене збудження & 30 & 20,5 \\
\hline & г) спокій & 5 & 13,5 \\
\hline & г) пригніченість & 0 & 0 \\
\hline \multirow{5}{*}{$\begin{array}{l}\text { 2. Використання } \\
\text { засобів розслаблення } \\
\text { перед стартом }\end{array}$} & а) використовую & 20 & 30 \\
\hline & б) іноді & 30 & 25 \\
\hline & в) майже ніколи & 10 & 5 \\
\hline & г) немає в цьому потреби & 15 & 20 \\
\hline & г) не замислювався про це & 25 & 20 \\
\hline \multirow{5}{*}{$\begin{array}{l}\text { 3. Формування } \\
\text { оптимального } \\
\text { передстартового } \\
\text { стану }\end{array}$} & a) прагну зняти напругу & 15 & 0 \\
\hline & б) викликаю приємні спогади & 13,4 & 0 \\
\hline & в) зосереджуюсь & 51,6 & 50 \\
\hline & г) використовую ПРТ & 20 & 10 \\
\hline & г) нічого не використовую & 0 & 40 \\
\hline \multirow{5}{*}{$\begin{array}{l}\text { 4. Характер } \\
\text { поведінки } \\
\text { з незнайомими } \\
\text { учасниками } \\
\text { змагання }\end{array}$} & а) спокійне очікування & 65 & 45 \\
\hline & б) підвищене збудження & 25 & 11,6 \\
\hline & в) пригніченість & 10 & 20 \\
\hline & г) розгубленість & 0 & 0 \\
\hline & г) невпевненість & 10 & 23,4 \\
\hline \multirow{5}{*}{$\begin{array}{l}\text { 5. Характер } \\
\text { поведінки } \\
\text { в випадку } \\
\text { переваги } \\
\text { суперників }\end{array}$} & a) активна участь & 55 & 70 \\
\hline & б) спокій & 20 & 30 \\
\hline & в) пасивність & 5 & 0 \\
\hline & г) аби пробігти & 20 & 0 \\
\hline & г) відмова від забігу & 0 & 0 \\
\hline \multirow{5}{*}{$\begin{array}{l}\text { 6. Реакція на } \\
\text { допущені } \\
\text { помилки в техніці }\end{array}$} & а) продовжую в тому самому темпі & 25 & 36,7 \\
\hline & б) прояв обережності & 51,7 & 46,7 \\
\hline & в) бувають неточні дії & 20 & 16,6 \\
\hline & г) сильно хвилююся & 3,3 & 0 \\
\hline & г) утрата самовладання & 0 & 0 \\
\hline \multirow{5}{*}{$\begin{array}{l}\text { 7. Характер } \\
\text { поведінки } \\
\text { після невдалого } \\
\text { виступи }\end{array}$} & a) спокій & 5 & 15 \\
\hline & б) аналіз допущених помилок & 60 & 55 \\
\hline & в) прояв невпевненості & 15 & 15 \\
\hline & г) погіршення настрою & 20 & 15 \\
\hline & г) небажання далі займатися & 0 & 0 \\
\hline \multirow{5}{*}{$\begin{array}{l}\text { 8. Характер } \\
\text { поведінки після } \\
\text { успішного } \\
\text { виступи }\end{array}$} & a) задоволений собою & 40 & 50 \\
\hline & б) бажання далі тренуватися & 48,3 & 40 \\
\hline & в) сильно збуджений & 6,7 & 1,7 \\
\hline & г) міг би краще & 5 & 8,3 \\
\hline & г) пригноблений & 0 & 0 \\
\hline
\end{tabular}


Дослідженням установлено, що 20 \% висококваліфікованих спринтерів у своїй практиці перед стартом використовують засоби заспокоювання й розслаблення. До них відносять різні спеціальні психорегулювальні комплекси фізичних вправ, масаж, засоби саморегуляції, музичний супровід та ін., $30 \%$ - атлетів такі засоби використовують іноді, $10 \%$ - майже ніколи, $15 \%$ - не бачать у цьому потреби.

Серед спринтерів другої групи лише 30,0 \% застосовують засоби заспокоювання й розслаблення, a $25,0 \%$ роблять це нерегулярно.

Тренерами зазначено, що під час формування оптимального передстартового стану половина атлетів першої та другої групи найчастіше прагнуть зосередити свою увагу на майбутньому старті. 20,0 \% висококваліфікованих спринтерів використовують ПРТ або стараються зняти напругу за допомогою приємних бесід із членами команди, тренерами й спогадами про свої найкращі виступи. Серед спортсменів нижчої кваліфікації виявлено 40 \%, які до цього ставляться байдуже: « ... як пробіжу, так пробіжу».

Багатьма дослідниками підкреслено роль присутності потенційного сильнішого супротивника, який може вплинути на змагальний результат спортсменів $[4,11]$. У випадку переваги суперника, як указують тренери, 65,0 \% спринтерів перед забігом проявляють спокійне очікування старту, 25,0 \% відчувають підвищене збудження та $10 \%$ - пригніченість. Серед спринтерів нижчих розрядів 45,0 \% проявляють спокійне очікування старту, 11,6 \% відчувають підвищене збудження, 20,0 \% пригніченість і 23,4 \% - невпевненість у собі.

У ситуації, коли допускалися помилки на старті або в техніці бігу, як зазначили тренери, поведінка спортсменів в обох групах була практично однаковою. Найчастіше спринтери проявляють обережність, щоб не допустити фальстарту й уникнути дискваліфікації: у першій групі таких було $46,7 \%$, у другій $-51,7$ \%. Інші атлети не звертають уваги на помилки та продовжують діяти в тому самому темпі. У першій групі, за результатами опитування тренерів, виявлено 3,3 \% атлетів, котрі сильно хвилюються й проявляють пригніченість.

Під час аналізу поведінки спортсменів після невдалого виступу тренери зазначили, що більшість iз них аналізують допущені помилки, але при цьому в них знижується настрій і виявляється невпевненість у собі. У разі успішного виступу майже всі спортсмени задоволені собою (40-50 \%) i проявляють бажання тренуватися далі. Серед тих, котрі брали участь в анкетуванні, не було жодного спортсмена, який після успішного завершення змагання перебував би в стані пригніченості й апатії.

Отже, виявлення основних стрес-факторів, які впливають на психологічну готовність спортсмена до змагань, а також особливості їхньої поведінки напередодні та під час виступів дасть змогу тренеру краще спланувати роботу психологічного плану, допоможе оптимізувати передстартовий стан і тим самим покращити виступ атлетів на змаганнях.

Дискусія. Психологічна підготовка займає особливе місце в сучасному спорті. Спортсмен може бути добре фізично й технічно підготовленим, удало виступати та показувати високі результати на попередніх стартах, а на головних змаганнях не в змозі налаштуватись і достойно виступити. Щоб реалізувати повною мірою свої фізичні, технічні й тактичні здібності, навички та вміння, розкрити резервні можливості як обов'язковий елемент змагальної діяльності, легкоатлету потрібно постійно психологічно готуватися до змагальних стартів. Психологічна підготовка легкоатлета-спринтера до змагань $є$ важливим та обов'язковим елементом навчання й тренування. Правильне планування психологічної підготовки сприяє вдосконаленню передстартового стану, зниженню впливу стресфакторів і підвищенню рівня психологічної готовності до змагань.

Висновки. У процесі дослідження виявлено найбільш значні стрес-фактори, що негативно впливають на психіку легкоатлетів-спринтерів різної кваліфікації напередодні й під час змагання.

Для спринтерів високої кваліфікації такими попередні погані тренування та низькі результати змагань (78 \%); підвищене хвилювання і поганий сон за один або декілька днів до змагання (72 \%); надмірна напруженість на старті (50 \%); участь сильніших суперників (55\%); погане самопочуття, фізичний стан (40 \%); докори тренера (40 \%); попередня невдача на змаганні (42\%); негативні реакції глядачів (25\%).

Для легкоатлетів нижчого рівня підготовленості стрес-факторами є погані тренування й низькі результати змагань (66 \%); конфлікти з тренером, товаришами по команді або в сім’ї (70 \%); надмірна напруженість на старті (65 \%); підвищене хвилювання, поганий сон за один або декілька днів до змагання (40 \%); постійна думка про необхідність успішно виконати поставлені завдання (40 \%). 
Виявлені чинники вказують на необхідність навчати спортсменів контролювати поведінку і свій передстартовий стан. Це можна здійснювати за допомогою методів психорегулювального тренування, групових й індивідуальних бесід, психотехнічних вправ і розслаблювального масажу, що дасть можливість зменшити вплив значущих стрес-факторів і покращити результативність змагальної діяльності легкоатлетів-спринтерів.

Перспективи подальших досліджень. Наступні дослідження можуть бути спрямовані на вивчення рівня розвитку в спринтерів різної кваліфікації таких вольових якостей, як цілеспрямованість, сміливість, рішучість, наполегливість, витримка та самовладання.

\section{Джерела та література}

1. Волков В. Н. Определенные условия подготовки спортсменов к соревнованиям. Теория и практика физической культуры. Москва, 2001. № 3. С. 12-16.

2. Вяткин Б. А. Управление психическим стрессом в спортивных соревнованиях. Москва: Физическая культура и спорт, 1981. 112 с.

3. Ганюшкин А. Д. Идеальное состояние для выступления спортсмена как форма психической готовности. Спортсмен как субъект деятельности: сб. науч. тр. Омск, 1993. С. 23-25.

4. Ермолаева М. В. Адаптивная функция состояния тревоги в спорте. Теория и практика физической культуры. Москва, 1985. № 4. С. 5-7.

5. Кузнецов М. Предстартовое состояние легкоатлетов. Легкая атлетика. 1995. № 6. С. 12-15.

6. Лалаян А. А. Психологическая подготовка спортсмена к конкретному соревнованию. Ереван: Айстана, $1975.54 \mathrm{c}$.

7. Малкин В. Р. Формирование психической соревновательной надежности спортсмена. Cпортивныци психолог. 2004. № 2. С. 33.

8. Медведев В. В. Основы и методы регуляции и саморегуляции психических состояний спортсмена. Лекция для студентов ГЦОЛИФК. Москва, 1989. 22 с.

9. Новиков М. А. Социально-психологические аспекты эмоционального стресса в спорте. Maтериаль второго Всесоюзного симпозиума «Психический стресс в спорте». Пермь, 1995. С. 61-66.

10. Озолин Н. Г. Настольная книга тренера. Москва: Изд-во «Астрель», 2004. 863 с.

11. Платонов В. Н. Система подготовки спортсменов в Олимп. спорте. Общая теория и ее практические приложения. Киев: Олимп. лит., 2004. 808 с.

12. Родионов А. В. Влияние психологических факторов на спортивный результат. Москва: Физическая культура и спорт, 1983. $112 \mathrm{c}$.

13. Сопов В. Ф. Теория и методика психологической подготовки в современном спорте. Москва: Трикста, $2010.116 \mathrm{c}$.

14. Хекалов Е. М. Неблагоприятные психические состояния спортсменов, их диагностика и регуляция: учеб. пособие. Москва: Сов. спорт, 2003. 64 с.

15. Чикова О. М. Психологические особенности спортивной деятельности и личности спортсмена: [учеб. пособие для училищ Олимп. резерва]. Минск: Госэкономплан РБ, 1993. 76 с.

\section{References}

1. Volkov, V. N. (2001). Opredelennye uslovija podgotovki sportsmenov k sorevnovanijam [Certain conditions of the athletes preparation for competitions]. Teorija i praktika fizicheskoj kul'tury [Theory and practice of Physical Education], 3, 12-16.

2. Vjatkin, B. A. (1981). Upravlenie psihicheskim stressom v sportivnyh sorevnovanijah [Management of mental stress in sports competitions]. Fizicheskaja kul'tura i sport [Physical Culture and Sports], 112.

3. Ganjushkin, A. D. (1993). Ideal'noe sostojanie dlja vystuplenija sportsmena kak forma psihicheskoj gotovnosti [The ideal state for the athlete's performance as a form of mental readiness]. Sportsmen kak subjekt dejatel'nosti: sbornik nauchnyh trudov [Athlete as a subject of activity: collection of scientific papers], 23-25.

4. Ermolaeva, M. V. (1985). Adaptivnaja funkcija sostojanija trevogi v sporte [Adaptive function of anxiety state in sport]. Teorija i praktika fizicheskoj kul'tury [Theory and practice of Physical Education], 4, 5-7.

5. Kuznecov, M. (1995). Predstartovoe sostojanie legkoatletov [Prelaunch state of athletes]. Legkaja atletika [Athletics], 6, 12-15.

6. Lalajan, A. A. (1975). Psihologicheskaja podgotovka sportsmena k konkretnomu sorevnovaniju [Psychological preparation of an athlete for a specific competition]. Erevan: Ajstana.

7. Malkin, V. R. (2004). Formirovanie psihicheskoj sorevnovatel'noj nadezhnosti sportsmena [Formation of the mental competitive reliability of an athlete]. Sportivnyj psiholog [Sports psychologist], 2, 33.

8. Medvedev, V. V. (1989). Osnovy i metody reguljacii i samoreguljacii psihicheskih sostojanij sportsmen: Lekcija dlja studentov GCOLIFK [Fundamentals and methods of regulation and self-regulation of the athlete's mental states: lecture for students of SCOLIFK]. 
9. Novikov, M. A. (1995). Social'no-psihologicheskie aspekty jemocional'nogo stressa v sporte. [Socio-psychological aspects of emotional stress in sports]. Materialy vtorogo Vsesojuznogo simpoziuma «Psihicheskij stress v sporte» [Materials of the second All-Union Symposium «Mental stress in sports»], 61-66.

10. Ozolin, N. G. (2004). Nastol'naja kniga trenera [Handbook of the coach]. Moscow: «Astrel».

11. Platonov, V. N. (2004). Sistema podgotovki sportsmenov v Olimp. sporte. Obshhaja teorija i ee prakticheskie prilozhenija [The system of athletes training in Olympus. sports. General theory and its practical applications]. Kiev: Olimp. lit.

12. Rodionov, A. V. (1983). Vlijanie psihologicheskih faktorov na sportivnyj rezul'tat [The influence of psychological factors on athletic performance]. Moscow: Fizicheskaja kul'tura i sport.

13. Sopov, V. F. (2010). Teorija i metodika psihologicheskoj podgotovki v sovremennom sporte [Theory and methodology of psychological preparation in modern sport]. Moscow: Triksta.

14. Hekalov, E. M. (2003). Neblagoprijatnye psihicheskie sostojanija sportsmenov, ih diagnostika i reguljacija: ucheb. posob. [Adverse mental conditions of athletes, their diagnosis and regulation: textbook]. Moscow: Sov. sport.

15. Chikova, O. M. (1993). Psihologicheskie osobennosti sportivnoj dejatel'nosti i lichnosti sportsmena: uchebnoe posobie dlja uchilishh Olimpijskogo rezerva [Psychological features of sports activities and the personality of an athlete: [Textbook for schools of the Olympic reserve]. Minsk: Gosjekonomplan RB.

Стаття надійшла до редакції 23.08.2020 р. 